Binghamton University

The Open Repository @ Binghamton (The ORB)

The Society for Ancient Greek Philosophy Newsletter

$12-1966$

\title{
The Creation Myth in Plato's Timaeus
}

Leonardo Taran

Columbia University, It1@columbia.edu

Follow this and additional works at: https://orb.binghamton.edu/sagp

Part of the Ancient History, Greek and Roman through Late Antiquity Commons, Ancient Philosophy Commons, and the History of Philosophy Commons

\section{Recommended Citation}

Taran, Leonardo, "The Creation Myth in Plato's Timaeus" (1966). The Society for Ancient Greek Philosophy Newsletter. 252.

https://orb.binghamton.edu/sagp/252

This Article is brought to you for free and open access by The Open Repository @ Binghamton (The ORB). It has been accepted for inclusion in The Society for Ancient Greek Philosophy Newsletter by an authorized administrator of The Open Repository @ Binghamton (The ORB). For more information, please contact ORB@binghamton.edu. 


\section{"The Creation Myth in Plato's Timaeus"}

by Leonardo Tarán

The purpose of this paper is to discuss the question whether the creation myth in Plato's Timaeus is to be taken literally or not. My reason for reopening the discussion is the recent publication by Professor. Vlastos of a paper entitled "Creation in the Timaeus: is it a Fiction?" (1) In this paper Vlastos tries to answer the arguments that Professor Cherniss (2) gave in favor of the metaphorical interpretation, in the course of which arguments he attacked Vlastos' earlier article "The Disorderly Motion in the Timaeus". (3) My reason for concentrating on Professor Vlastos' papers is that his is the most recent and most complete statement of the question among those who consider that the creation of the world was meant by Plato literally. (4) I have learned a Iot from Professor Vlastos' arguments and my disagreements with his views should not be taken as implying lack of respect for them; Professor Vlastos is a scholar to whom I feel greatly indebted both from the scholarly and the personal point of view. I have learned many things from the many scholars who have argued for the metaphorical interpretation of the creation of the universe in the Timaeus, but since Cherniss' discussion is the latest, most complete and coherent presentation of this view, I shall take my point of departure from his treatment of the question, though here and there I shall refer to earlier discussions. (5)

The interpretation of the creation myth in the Timaeus is intimately connected with the problem of the origin of evil in Plato; since I believe, however, that it is necessary to elucidate first the former problem, I will postpone a systematic discussion of the latter for another occasion. (6)

In the Timaeus, the myth of the creation of the world is part of another and larger myth: that of the victory of ancient Athens over Atlantis. The latter is brought about by Critias' desire to requite Socrates for the conversation held "yesterday." in the course of which Socrates had shown the nature of the ideal state. (7) The purpose of the story of Atlantis is to identify the ideal state with ancient Athens and thereby satisfy Socrates' desire to see his ideal society in action so to say. (8) But before this can be treated in full, (9) it is necessary that Timaeus, an eminent philosopher, astronomer, and physicist, (10) should tell first the story that starts with the birth of the universe and ends with the nature of man. (1I)

It seems, then, that the purpose of the creation myth is to give an account of the nature of man and of the universe to serve as the background for another mythical account, the purpose of which will be to show that the ideal state is superior and ultimately more powerful than an adversary which has greater material resources and skill but is morally inferior. (12) That the purpose of the creation myth is to give a systematic account of the nature of man and the world rather than a chronological report of how the world came into being, is, I think, undeniable; this systematic character of Timaeus' exposition can be seen even in the three main divisions of his discourse. There is first a prelude (27 C-29 D) (13) in which the nature and the limits of the exposition are set down. (14) Timaeus deals then with the work of the Demiurge and of the created gods (29 D-47 E) which constitutes the work of Reason in the universe. At $47 \mathrm{E} \mathrm{ff.,}$ however, he declares the need to begin all over again and introduces the third factor, the receptacle; this is done in order to describe what comes about of Necessity (47 E$69 \mathrm{~A})$. We hear now of things that the Demiurge had done before some of those described in $29 \mathrm{D}-47 \mathrm{E}$. (15). In the third and last part of the myth (69 A-92 C), after recapitulating the two previous sections, Timaeus explains the creation of those things which are a result of the cooperation of Reason and Necessity. There is, I think, a plausible reason for Plato's choice of this order of narration; (16) at present it is sufficient to notice that Plato gives a systematic account of, and is interested in, the two causes which are at work in the universe and that to give this systematic account he decided to do away with the chronological order, placing "first" what was chronologically "second." 
The systematic character of the creation myth in the Timaeus, with the consequent abandonment of the chronological order of creation, is sufficient to place it in a different category from other creation myths. By itself, however, the systematic character of the narrative does not yet imply that the creation of the world was not meant by Plato to be taken literally. But if we discover indications, in the Timaeus itself, that the creation was not meant to be taken literally, then we would be entitled to concluding that Plato purposely chose the form of a creation myth in order to give a systematic account of the nature of man and of the universe. (17) In that case, we should not put special emphasis, for example, in the fact that Plato speaks of a precosmical state of things or talks as if the universe was really created by the Demiurge; for Plato was a great artist and once he had decided to explain the nature of the universe in the form of a genetic myth he was naturally going to do whatever seemed necessary to preserve the likelihood of the creation myth. (18) What I mean to say is that the burden of the proof lies with those who claim that Plato did not intend the creation of the universe to be taken literally; but if we find as much as one clear indication in the Timaeus itself that Plato is warning the reader not to take the chronological account literally, or that he is pointing out a contradiction which would disappear if the creation is interpreted metaphorically, then we would be entitled to interpret the chronological account as a mean used by Plato to analyze the different factors and causes acting in the universe as it is. It is neither impossible nor unlikely that Plato may have decided to explain his conception of the universe through a creation myth: (19) that much, I think, should be granted by those who interpret the Timaeus literally. The discussion should, then, be centered on the arguments given to show the metaphorical character of the cosmogony.

I

Though the order of creation is not followed in the narrative, it is legitimate to put together all that is said about it in the myth and thereby reconstruct the temporal order of creation. If, in doing this, we find contradictions, contradictions that could only be removed by a different order of narration which would entail a modification of Plato's account of a part of the universe, then it would be legitimate to conclude that Plato did not mean the creation to be taken literally, unless there were strong reasons to believe that he was unaware of the contradictions that the true chronological order of creation would introduce. In fact, one sufficiently decisive argument in favor of the metaphorical interpretation are the contradictions which would be patent if the true chronological order were followed in the account of the creation of the body and the soul of the universe. This argument is not based, as Professor Vlastos thinks, (20) only on the fact that the order of exposition does not follow the chronological order. If this were the same case as when a historian narrates in the order $C, A, B$, three facts that chronologically had the order $A, B, C$, Vlastos would be right in considering that this is not a valid argument to prove that the account of the creation of the body and the soul of the universe should not be taken literally. But if Plato himself calls attention to the fact that the order of creation is not the order followed in the narrative, and if we are able to show that, had he followed in the narrative the mythical order of creation, this would introduce contradictions which a different order of narration from the one chosen could not remove without changing the content of the account, then we would be right in contending that this proves the metaphorical character of the creation myth.(2I)

Plato describes first the creation of the body of the universe (22) and after this the creation of its soul. (23) But, before starting to describe the creation of soul, Timaeus explains that though in the narrative body is dealt with first and soul second, soul is really prior to body in birth and excellence, the reason being that soul must be prior to body if it is to rule it. (24) "The reversal of the "chronological" order of creation is said to be due to the fact that "there is in us too much of the casual and random, which shows itself in our speech". (25) This "casual and random" must be understood in the light of those "secondary causes" referred to in $46 \mathrm{E}$. -6 . (26) But it is clear that Plato could not have meant this explanation of the reversal suffered by the 
mythical order in the narrative to be taken literally, for he is himself warning us that the chronological order has been reversed and, consequently, he could have modified the

- order of narration if he so wished. The reversal and the warning look, then, as a conscious device to call attention to the fact that "prior" and "posterior, "or "older" and "younger," should not be taken in the temporal sense. (27) Moreover, when we read the paragraph devoted to the creation of the soul we see one reason at least for the order chosen by Plato in his narrative. In $35 \mathrm{~A} 1-8$, the soul is constructed as intermediate between the ideas and body, and as an intermediate it presupposes the extremes between which it is an intermediate; (28) from this it follows that soul cannot really be temporally prior to body.

(29) Consequently, if the account of the structure of soul and body given in Timaeus $3 I$ $\mathrm{B}-35 \mathrm{~A}$ is serious Platonic doctrine, soul and body must be contemporaneous (see also note 47); and, since soul is said to be "prior" and "older" than body, it follows that these words must refer to ontological and not to chronological priority. (30) Had Plato followed the mythical order of creation in his narrative he would have been forced to modify his account of the creation of the soul; the implications of the order of narration here are, then, intimately connected with the content of Timaeus' discourse and cannot be compared to the method of a historian when he chooses to give flashbacks to illuminate a later event.

II

There is in the Timaeus another device by which Plato probably meant to indicate that the creation of the soul and the body of the universe should not be interpreted literally. This device consists in the omission, which must have been conscious as we will see, of a factor which, if openly mentioned, would destroy the likelihood of the creation myth. Both in the Phaedrus and in the Laws Plato maintains that the soul is self-motion and the source of ali other motion. (3I) I do not wish to discuss in this paper the argument that the soul as self-motion must be eternal; but even if Vlastos were right in his interpretation that in the Laws soul is a "created" entity, still even there the essence of the soul is said to be self-motion and because of this the soul is declared to be the source of all motion. (32) In the Timaeus there are several references to this notion that the soul is self-motion; (33) yet it is never openly stated that this is the essence of the soul and, significantly enough, all reference to self-motion is omitted from the psychogonia, the place where we would naturally expect Plato to mention it. I submit that the reason for this omission must be that, if self-motion were openly stated to be the essence of the soul, this statement would destroy any likelihood that the creation myth could have. Vlastos for his part asserts that there is no contradiction in the fact that self-moving. souls should be created; but if this were the case, why did Plato omit all reference to self-motion in the psychogonia?

Professor Vlastos, if I understand him correctly, would say that there is no omission at all; for in answer to another argument, that it is contradictory to have a soul create all the other souls, (34) he maintains that we should distinguish between (A) the Craftsman generates self-moving souls and $(B)$ he generates the self-motions of self-moving souls. Vlastos thinks that the Timaeus refers to the first alternative, not to the second. His argument is: "B is obviously self-contradictory, since the very description of the motion of a given soul' as a 'self-motion' entails, in Plato's scheme, that it is caused by just that soul and by no other individual in the universe - hence, a fortiori, not by the Demiurge. But $B$ is never mooted in the Timaeus, where the Craftsman creates souls and leaves them alone to do their own self-moving for ever after. How then could A, once it is clearly distinguished from $B$, involve a contradiction? What is there to keep the Demiurge (assuming he has the wonderfuI powers of world-creation) from creating entities that have the power of self-moving and, once created, go on to exercise this power to their heart's content?" (35)

But where does Vlastos find evidence for statement A? It is never said in the Timaeus that the Demiurge created a soul, or souls, and that afterwards they start to do their own self-moving. This is, then, an inference on the part of Vlastos, an inference prompted by the fact that the relation of the soul to self-motion is never openly stated, as we said. (36) 
Plato, however, means that the soul is identical with self-motion, not that it has the

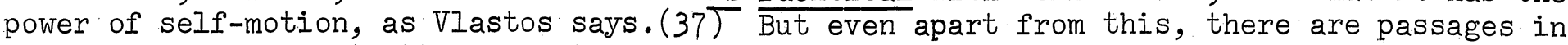
the Timaeus which definitely point to $B$ in regard to the world-soul and, a fortiori, for all souls. The first such reference occurs in the passage that we discussed in the previous section, i.e. Timaeus 3I B-35 A. After describing the creation of the body of the universe and after explaining why the Demiurge gave to it a spherical shape with neither eyes nor ears, neither hands nor feet, Timaeus says that the Demiurge imparted movement to the body of the universe, "that one of the seven which above all belongs to reason and intelligence". (38) But this motion imparted to the universe must be the motion of the world-soul (39) which, as we are told almost immediately, (40) was created before the body of the universe. Moreover, whereas in the psychogonia (4I) there is no mention at all of self-motion or of any other motion that is proper to the soul, in $36 \mathrm{C}-\mathrm{E}$ the Demiurge, after "splitting" the soul into the circle of the Same and the circle of the Different, does the following things: he "enveloped" the circles with the motion that is carried around uniformly in the same place, (42) he "made" one the outer and the other the inner circle, (43) he caused the circle of the Same to move to the right and the circle of the Different to the left, (44) he gave supremacy to the revolution of the Same, (45) and the soul being inwoven with the universe and enveloping it on the outside "revolving within its own limit, made a divine beginning of ceaseless and intelligent life for all time." (46) All these actions of the Demiurge are incompatible with the voluntary self-motion of soul. (47)

It follows, then, that if the Demiurge really created the soul of the universe he started also its self-motion. But why did Plato not say so openly? Because, I think, it is self-contradictory to state that the Demiurge started the self-motion of the soul, as VIastos himself recognizes. On the other hand, Plato could not suppress all reference to selfmotion, since this would falsify his teleological conception of man and of the universe. (48) We are now able to discover one more reason for Plato's decision to relate first the creation of body; had he done otherwise he would have faced two alternatives which he could not accept: (a) either to state openly that the Demiurge started the self-motion of the world-soul, or (b) that he created a soul, attached it to a body created afterwards, and that after this the soul, by its own power, started its never-ending motion. The second alternative is Vlastos' interpretation; but the fact that Plato did not choose it and that he preferred instead to have the Demiurge "envelop" the soul with motion and impart motion to the body of the universe, a motion that is the movement given to the universe by its soul, shows that Plato, by calling attention to the reversal in the narrative of the chronological order of creation (with the explanation that soul must be "older" than body if it is to govern it, i.e. move it), meant to suggest to the reader that the creation should not be taken literally.

Plato was not trying to deceive his reader; he chose a genetic myth over a direct analysis of the causes at work in the universe (49) and, once he had chosen this form of exposition, he had to preserve the likelihood of the mise-en-scène. To reach the conclusion that the creation of the universe should not be taken lit $\overline{e r} \overline{l l y}$, it is not necessary that the reader be acquainted with the Phaedrus (50) and the Laws; for the notion that soul is selfmotion is implied in the Timaeus, as is also the notion that the world-soul moves the universe. And, finally, the Timaeus states unambiguously that soul is primary causation as opposed to the secondary or "necessary" causes. (51) If Plato never openly states in the Timaeus that the soul as self-motion is the ultimate source of all motion, it is not to openly contradict what he said about the precosmical chaos, which is the symbol of the "necessary" causes, even as the Demiurge is the symbol of the intelligent causation of the self-moving soul.

\section{III}

Plato declares that time and the universe came into being simultaneously, that no time existed before the universe and that none would exist if the universe were ever destroyed. (53) Yet events are described which took place before the creation of time. This looks like a contradiction, a contradiction of which Plato must have been aware, since he emphatically asserts several times that time and the universe are contemporaneous. These assertions can 
only be interpreted as a device to call the reader's attention to the fact that, as there was no time when the universe did not exist, neither the universe nor time ever came into being.

Vlastos, however, asserts that Plato, in Timaeus 37 D-38 A, speaks only of a time (U) which can be defined as uniform and measurable time-flow, and he maintains that this is different from saying that the Demiurge introduced temporal succession, or time-flow as such, into the world. The latter Vlastos calls time $(S)$ and defines as irreversible temporal succession. Vlastos maintains that this distinction would eliminate the contradiction mentioned above and, although he admits that Plato did not make this distinction, he asserts that what Plato says about time in the Timaeus shows that he did not deny the proposition that time $(S)$ is instantiable in the absence of time (U). (54) He then goes on to say: (55) "Nor is there any evidence that he (sc. Plato) had made the analysis that would have enabled him to do this by revealing how time (U) was both different from, yet related to, time (S). He is perfectly capable, certainly, of thinking and speaking of time in other contexts in terms of the past/present/future distinction without specific reference to measurable timeflow: he does so in the Parmenides (15' E-157 B). But there is no indication there, or anywhere else, that he saw precisely how these two concepts are related. We should do well to keep in mind that no one in antiquity succeeded in seeing this - not Aristotle, for example, who wrote more extensively on time, with greater analytical thoroughness, and with knowledge of what Plato had already contributed to the partial exploration of this difficult concept."

I have italicized the last part of the quotation because I wish to emphasize that the distinction that Vlastos thinks so difficult to make was indeed made in antiquity; and I think that such a distinction would have been made by Plato if he meant even to leave open the possibility of a precosmic time. At any rate, the distinction between a precosmic time and a cosmic, "ordered," time is made by the Epicurean Velleius in Cicero's De Natura Deorum and, interestingly enough, the distinction is made in a passage where Plato's Timaeus is being criticized.(56) Moreover, Aristotle himself must have been aware of such a distinction, since he reports that whereas Plato held that both time and the world were created, all his predecessors held that the universe was generated, leaving time as ungenerated. (57) Whether or not Aristotle is accurate here in his report, there can be no question that he must have been aware of the distinction between precosmic and cosmic time. Moreover, even if Plato could not make such a distinction, if he really meant the creation to be taken literally, he would, like some of the Presocratics at least, have left time as ungenerated. His emphatic assertions that time and the universe were generated together, that God created the

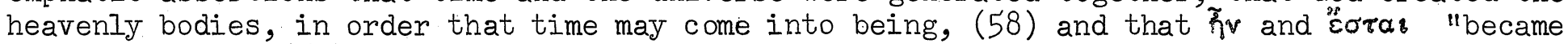
forms of time", (59) can only be interpreted as his way of indicating to the reader that there was no time when the universe did not exist, i.e., the universe must have existed always.(60) These expressions, in the absence of any indication to the contrary, imply a denial of the possibility of time (S) or precosmic time; (6I) unless we are willing to admit that Plato was unaware of the contradiction that his statements about time imply. A very unlikely prospect, I think; the more so, if we consider that these expressions were interpreted as contradictions in antiquity, both by those who, interpreting the Timaeus literally, attacked Plato, (62) and by those who, considering that these statements imply a contradiction (namely, "there was a time when time was not") (63), considered that Plato tried to indicate that the creation of the world should not be taken literally. Neither Plato nor Aristotle distinguish a cosmic from a precosmic time because, believing that the cosmos is eternal, they did not need to make such a distinction.(64)

\section{IV}

After creating soul, the body of the universe, the heavenly bodies, and the gods of traditional mythology, the Demiurge passes on the task of creating the other three kinds of living beings to the created gods.(65) It is then said of the Demiurge: kai o $\mu \dot{\varepsilon} v$

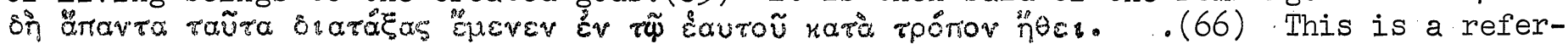
ence to the doctrine that God is unchangeable; and Proclus already noticed that to be always 
In the same state in relation to the world the Demiurge must create always, if he creates at all (i.e. the universe must be eternal).(67) If the Demiurge created the universe at a certain time and then ceased creating, his relation to the universe must have changed.(68)

- This doctrine that God is unchangeable is explicitly stated and explained in the Republic(69) and is in agreement with Plato's conception of the divine as expressed in other dialogues.

Vlastos, however, says that "the constancy of God's hoos would comport with any amount of world-making, provided only his behavior as Craftsman remains consistent with his character as god. In Rep. $381 \mathrm{C}$, the point of the statement that lit is impossible for a god to wish to change himself but, as is only right, each of them being as fair and excellent as it is possible to be, abides for ever in his own character,' is not that god does not act at all, but that he does not act in undignified and wicked ways: he does not lie, masquerade, etc., like the Homeric deities; he never causes evil, only good ( 379 B-380 C). Since the world creation is an act of supreme beneficence (30 A-B), it nould imply no. shift of nature or character in this "best of causes" (29 A), but rather a fitting expression of it." (70)

But what Vlastos quotes from the Republic is only 381 C 7-9, and these lines are only the conclusion of the argument that shows that God must be unchangeable. Granting that in the Republic it is Plato's purpose to show that God cannot wish to lie, masquerade, etc., how is this proved? It is proved by a general argument the import of which is to establish that God, if he changes at all, must change for the worse, since he is as good and beautiful as possible.(71) This same doctrine is echoed in the Timaeus. If the Demiurge really created the world because he wanted everything to be as good as possible, since there is no pөóvos in the divine, (73) then, why, if this act of creation is good, did the Demiurge create the world at one time rather than at another? If God is good and he always possessed this power of creation, why did he allow the precosmic chaos to exist for some time before he decided to bring order into it?(74) If the creation is interpreted literally, it would imply that a change took place in the divine $\tilde{h} \theta 05$ from worse to better, a notion incompatible with what is said in the Timaeus about the Demiurge.

The notion of a god starting the creation of the world at a certain point in time presupposes a divinity powerful enough to: create his own values; but such a thing is incompatible with Plato!s conception of the divine. For Plato God, or a god, is soul (75) and as such it must be subordinated to the ideas. In the Euthyphro, undoubtedly an early work, it is said that the holy is loved by the gods because it is holy and not that it is holy because it is loved by the gods.(76) In the Laws, his last work, Plato asserts that there are $\theta \varepsilon \tilde{\imath} \alpha$ s ávåruawhich bind even the gods and against which the gods do not and will never fight; (77) in fact, it is a condition for the existence of the divine the knowledge and practice of these $\theta \varepsilon \tilde{i} a r$ avarka . (78) The same thing is meant in the Phaedrus when the life of the gods is described in mythical terms as the contemplation by NOUS of the úrepoupávios tónos, (79) a contemplation that must be eternal, (80) since it is "contact" or "closeness" to the ideas that makes a god divine.(81) Only man searches and seeks wisdom, only man can be a pidóoopos; a god does not need to search, for he is already wise, as we are told in the Symposium (204 A). Even the heavenly bodies are considered to be divine because they do always the same thing (Timaeus, Laws), and this is considered the proof that they are alive and that their movement is voluntary. The nature of the Platonic god being what it is, he could not start capriciously to create the world because this work of creation is good. If he creates, he must create always; and, since this is incompatible with what is expressed in Timaeus $42 \mathrm{E} \mathrm{5-6,} \mathrm{we} \mathrm{must} \mathrm{interpret} \mathrm{the} \mathrm{Demiurge} \mathrm{as,} \mathrm{a} \mathrm{mythical}$

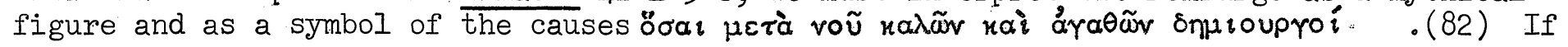
the Demiurge is mythical and is a symbol of intelligent causation, this would explain why the distinction between "God," "the God," and "the gods" is not maintained (83) after the created gods are introduced at $41 \mathrm{~A}-\mathrm{D}$. 
The use of the figure of the Demiurge is not restricted to the Timaeus; we find it also in the Sophist (84) and in the Politicus (85) (in the latter we also find the precosmic disorderly motion).(86) It cannot be a development in Plato's "later" works, since we - find it even in the Republic, (87) where it is said that the Demiurge fashioned the heaven

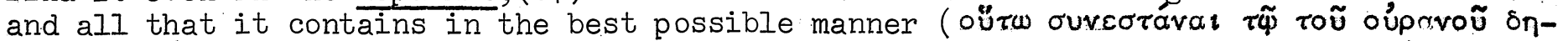

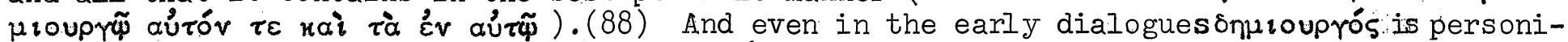
fied and applied to Rhetoric and to other $\tau \dot{x} \times v a$. (89) Aristotle himself, who certainly considered the cosmos to be ungenerated and imperishable, said that God made coming to be perpetual as the closest approximation to real being that is possible for sensible existence. (90) It is also to be noticed that Aristotle, who interpreted the Timaeus literally, pays no attention to the Demiurge.(91)

Have I not forgotten, however, what may be in fact the most important argument to assert that according to Plato the universe came into being? Is it not decisive that Plato himself says that the cosmos reyover ?(92) Such has always been the claim of those interpreters who take the creation of the world in the Timaeus literally. Moreover, Hackforth, (93) followed by Vlastos, (94) argues that the sentence in which Plato asserts that the universe has been generated, having started from an ápxń, (95) is demonstrated (96) from premises which express serious metaphysical doctrine, with no metaphorical or mythological language at all. The premises by which it is proved that the cosmos came into being are, according to Vlastos, (97) two: (1) it is corporeal and as such it is an object of sense perception and belief, while (2) all such objects are in process of becoming and have been generated.

Zeller, (98) followed by Cherniss, (99) had objected to (2) on the ground that, if all that is visible must have come into being, this must also be true of the precosmical chaos; the latter is said to exist before the universe was created and as such it is said to have been visible.(100) Vlastos maintains that "Plato's cursory reference to the primal chaos in $30 \mathrm{~A}$ as 'all that was visible' is one of the most obscure of his remarks about that all too obscure subject" and that it is contradicted by the assertion in 31 B 5 that nothing is visible unless it has fire in it, "but chaos had only an inchoate antecedent of fire which did not have the nature of fire but only 'certain traces' of it (53 B 2). How and in what sense this would or could be 'visible' Plato does not explain." Consequently, according to Vlastos, this very silence would be enough for Plato to escape Zeller's charge of contradiction, or at the very least it would not be a glaring contradition but, at best, an unexplained obscurity. Moreover, if Zeller's charge would be valid, "it would put Plato in the position of palming off on his readers falsehoods in the major premise and conclusion of our syllogism. Believing that it is quite false that all objects of sense-perception and belief are generated, and also false that the world was generated, Plato would be making his mouthpiece, Timaeus, assert the first and join it to a true premise to engender a false conclusion." (101)

I do think, however, that Zeller's argument is valid; for it is a fact that Plato calls the precosmic chaos "visible" and, whatever may be the obscurities of Plato's conception of the precosmis chaos, if it is "visible," the reasoning of 28 B 7-C 3 would apply also to it. After all Plato might very well not give this information if it introduces a contradiction; or must one suppose that, even granting that Plato wrote that the precosmic chaos is visible inadvertently or without being able to see "clearly" the contradictions of such an obscure notion, he never re-read the Timaeus carefully before publication? If he wrote that the precosmic chaos is "visible" it must have been with full awareness of the implications that this entails in relation to the reasoning employed in 28 B 7-C 3. We must assume that he called the chaos "visible" in order to make it clear that it was sensible. Fortunately there is more evidence to support Zeller's thesis. Let us start by interpreting literally 28 A-C as Hackforth and Vlastos do. From 28 A 4-6 and B 7-C 3 we may conclude that réveoıs

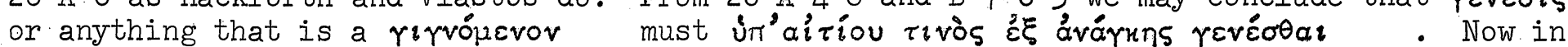
29 D 7-E.I it is said that God is the cause of genesis and of the universe. This genesis can be understood only as cosmic genesis, of which the Demiurge is the "father"; this is in 
agreement with the reasoning in $28 \mathrm{~A}-\mathrm{C}$. But later on it is said that Being, space, and genesis existed even before the generation of the universe.(102) There can be no question that this genesis, according to the reasoning in 28 A-C must have been "created" or must necessarily have a cause; but this would contradict the whole system of the Timaeus. Consequently, what Plato says about the precosmical chaos being "visible" and what he says about genesis introduces contradictions into the Timaeus. Is Plato, then, palming off falsehoods on his readers? I do not think so. My reason for this belief is that I consider that to judge any part of a Platonic work we should first read the whole of it; after all, Plato is not writing a treatise on mathematics or on logic. Many times Plato's works end in aporiae or contradictions and it seems to me that he leaves it to the reader to deduce by himself the implications of what is said literally in the work. The reasoning in $28 \mathrm{~A}-\mathrm{C}$ is, I think, correct. If we read the Timaeus and we find in it contradictions of which Plato was conscious and which seem to have been purposely included to call the reader's attention to them, is it so strange to conclude that Plato is thereby indicating to the reader that the creation of the world should not be interpreted literally? If, after reaching this conclusion, we come back to $28 \mathrm{~A}-\mathrm{C}$ we would naturally conclude that when $\mathrm{Plato}$ says that the universe "came into being" he meant only that it is "process," i.e., that the universe is always in the process of coming into being. There is no question that genesis and its derivatives can have this meaning and they were so interpreted by some in antiquity, in relation to this passage of the Timaeus.(103) Plato's point is, then, that the universe being a Yevniór must have a cause and that this cause is voũs and consequently soul. On the surface Plato seems to mean rérovevin the sense of something that came into being, not having existed previously; and this is only natural if he chose a genetic myth to explain the nature of the universe, a genetic myth with which Plato tried to illustrate by means of temporal succession the ontological structure of man and the universe.(104)

We may now also give an answer for the systematic order of the Timaeus. Had Plato chosen to give a purely chronological account of the creation of the world, this would have falsified his teleological conception of the universe; had he introduced the third factor from the very beginning, it would have contradicted his purpose of showing that the causation of soul is "primary," for it would have been obvious that the Demiurge is limited by the precosmic chaos. Plato, then, chose the order of narration that would best exemplify his notion that soul is primary causation and that soul is "prior" to body. This being so, according to $46 \mathrm{D}-\mathrm{E}$, soul must be the ultimate source of all motion. The importance that Plato attributed to this notion can be seen in the Phaedrus and in the tenth book of the Laws; a teleological explanation of the universe in which soul would be shown to be the master of body is, after all, the desiderata of Socrates even in the Phaedo. Nobody succeeded so well in fulfilling this task as Plato himself in the Timaeus.(105) 
- 1. This essay has been published in Studies in Plato's Metaphysics, edited by R. E. Allen (London, 1965), pp.401-419. Hereafter I shall refer to this essay as Vlastos, Creation.

2. Cf.H. Cherniss, Aristotle's Criticism of Plato and the Academy, vol. I, (Baltimore, 1944), pp.421-431; see also notes 314, 349, 382, 385. Hereafter I cite this work as Cherniss, I.

3. Originally published in Classical Quarterly XXXIII (1939), pp.71-83. The article is now reprinted in Studies in Plato's Metaphysics, pp.379-399. Since Vlastos has introduced some changes, I shall quote this paper from the studies and will refer to it as Vlastos, Disorderly Motion.

4. Hackforth's article "Plato's Cosmogony (Timaeus 27 D ff.), "Classical Quarterly, N.S.IX (1959), pp.17-22, the main argument of which has been accepted by Vlastos (Creation, pp.402-405), will be discussed in section $V$.

5. For references to the more important earlier publications, cf. Cherniss, I, note 357.

6. These publications are referred to and criticized by Cherniss in his article "The Sources of Evil According to Plato," Proceedings of the American Philosophical Society, 98 (1954), pp.23-30. For publications later than 1954 see those mentioned by Vlastos, Creation, p.402, note 1 .

7. Cf。 Timaeus 20 D-26 D.

8. Cf. Timaeus 19 D-20 C, 26 C-D, 27 A-B; Critias 110 C-D. See Cornford, Plato's Cosmology (Iondon, I937), pp. 2-8.

9. A summary is given in Timaeus $20 \mathrm{D}-25 \mathrm{D}$.

10. Cf. Timaeus $20 \mathrm{~A}$ and $27 \mathrm{~A}$.

11. Cf. Timaeus 27. A 5-6.

12. Cf. Taylor, Plato: Timaeus and Critias, translated into English with introductions and notes on the text (London, 1929), p.104.

13. Cf. Timaeus 29 D. 5 .

14. On this, cf. section $V$.

15. Such is the "generation" of fire, air, water, and earth, out of which the Demiurge was said to have created the body of the universe.

16. See section. V.

17. Cf. sections, I, II, III, and IV.

18. I mention this in view of Hackforth's argument, accepted by Vlastos, that in Timaeus 27 D 5-28 C 3 an argument is given which, being philosophically correct, would imply, if the creation was not meant literally, that Plato was deceiving his reader. I deal with this problem in section $V$.

19. He had used this device in the account of the four inferior constitutions in the Republic $\left(545^{\circ} \mathrm{C}-576 \mathrm{~B}\right)$ 。

20. Cf. Vlastos, Creation, p. 406. 
21. This is in fact the way in which the argument is presented by the defenders of the metaphorical interpretation; ef.,.e.g., Cherniss, I, pp. 424-5.

22. Timaeus 31 B $4 \mathrm{ff}$.

23. Timaeus 35 A 1 ff。

24. Timaeus 34 B 10-35 A I.

25. Timaeus 34 C 2-4. I have given Cornford's translation (Plato's Cosmology, p.59); my translations of the Timaeus all come from this work.

26. Cf. Cornford, op.cit., p. 59, note 1.

27. The notion that soul rules and is the master of body is good Platonic doctrine (cf., e.g., Gorgias 465 C-D; Phaedo 79 E-80 A, 94 E; Laws 892 A, 896 B-C, etc.); but this notion does not require that soul be temporally "prior" to body. This is implied in the Timaeus itself (cf。 notes 29 and 30). That Plato could use "prior" and "posterior" in a $\overline{\text { Iogical and }}$ ontological sense is shown also by Aristotle, Metaphysics 1019 A 1-4; though this passage is not a specific allusion to Timaeus 34 B-C, as Apelt (Beiträge zur Geschichte der griechischen Philosophie [Leipzig, 1891 ], pp. $226 \mathrm{ff.}$, especially p.228) thought, the distinction is here employed (cf. also Laws $892 \mathrm{C}$ and $896 \mathrm{C}$ ). See Mondolfo, I'Infinito nel pensiero dell' antichita classica ${ }^{2}$ (Firenze, 1956), p.109, note, and Cherniss, I, note 33.

28. Even the description of the middle element as a "mixture" of the two extremes is

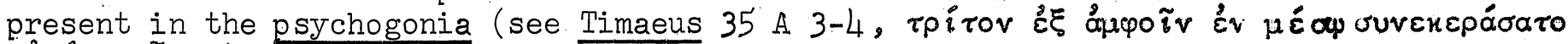

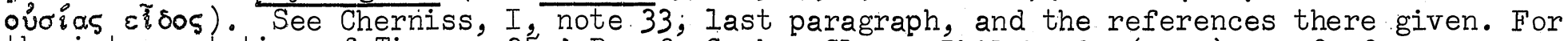
the interpretation of Timaeus 35 A-B, cf. Grube, Class. Philol. 27 (1932), pp.80-82.

29. The soul must be intermediate between the ideas and the body of the universe (cf.

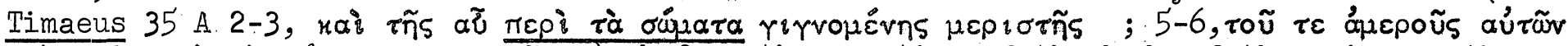

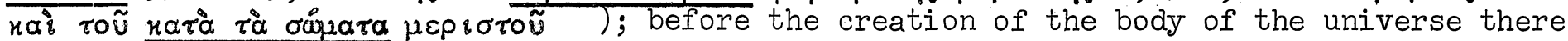
can be no bodies. If the soul were intermediate between the ideas and the precosmic chaos (but cf。note 30), then: either the soul would possess disorderly motion (but there is no mention in the Timaeus of disorderly motion in the soul, and, moreover, disturbance by sensation is introduced later $(43 \mathrm{~A}-44 \mathrm{~B}$ ) and sensation is the result of the incarnation of particular souls (42 A) and of the rectilinear motion of vision ( $45 \mathrm{C})$; see Cherniss, I, note 315$)$, or, if the "substraction" of the six motions in $34 \mathrm{~A}$ is interpreted to mean that the Demiurge did not need to impart motion to the body of the universe (but Plato says specifically that he did: 34 A I, arreveruev; cf. section II), the mere substraction of the six wandering motions being sufficient to start the motion of the universe (as Vlastos once maintained: Disorderly Motion, p.396), this would imply that the intelligent motion of the soul was already present in the precosmic chaos (cf. Cherniss, I, note 364 ).

30. If we insist both in interpreting "older" and "younger" in the chronological sense and in the literal interpretation of the Timaeus, contradictions appear when we consider the relation of the Demiurge to the precosmic chaos. Both are uncreated; yet the Demiurge, if not mythical, must be a soul (cf. note 34) and as a soul he must be "prior" to body or sensible existence and, at the same time, intermediate between sensible existence and the ideas. (If he is a soul he must be constituted in the same way as that described in 35 A, even assuming for the sake of the argument that the reference to sensible existence there is to the precosmic chaos [but cf. note 29].) At any rate, the Demiurge, as soul, governs the precosmic chaos and imposes on it a certain order; yet the Demiurge cannot be temporally "prior" to the precosmic chaos; if it were, the Demiurge must have created it, but such a notion is incompatible with the Timaeus. (For another contradiction if the Demiurge and chaos are taken literally, cf. section $\left.V_{0}\right)$ 
31. Cf. Phaedrus 245 C-246 A; Laws 895 A-896 B. Vlastos now admits that in the Laws soul is the source of all motion (Disorderly Motion, p.396, note l), whereas he previously tried to reconcile the Iaws with a literal interpretation of the Timaeus (cf.op.cit., pp. 397-399).

32. Cf. Laws $895 \mathrm{~A}-\mathrm{B}, 896 \mathrm{~A}-\mathrm{B}$.

33. Cf. Timaeus 37 B 5, 77 C 4-5, 89 A 1-3. The doctrine is also implied at Timaeus $46 \mathrm{D}-\mathrm{E}$, where the causality of NOUS, and consequently of the soul (cf. note 34 ) is declared to be primary.

34. The Demiurge, if not mythical, must be a soul, since his work is that of NOUS (47 E 3-4) and NOUS exists only in soul (30 B 3 and $46 \mathrm{D} \mathrm{5-6).} \mathrm{Cf.} \mathrm{Cherniss} \mathrm{I,} \mathrm{p.} \mathrm{425,} \mathrm{and} \mathrm{pp.}$ $603 \mathrm{ff.}$; this is accepted by Vlastos. What is said about the creation of the soul in $34 \mathrm{~B}-$ $35 \mathrm{~A}$ (cf. notes 28, 29, 30) shows that it is inconsistent to have the Demiurge create all the other souls. Moreover, whether the soul is "generated" or "ungenerated" cannot be an accidental characteristic of it if the soul is self-motion (cf. below this same section); consequently, if all the other souls were created by the Demiurge, this would introduce a contradiction in Plato's conception of the soul.

35. Cf. Vlastos, Creation, p. 416.

36. This is why Cherniss, I, p. 428, said that the passages quoted in note 33 are hints or veiled reminders of self-motion. These texts presuppose the notion of self-motion, but they do not discuss it nor do they state openly that this is the essence of the soul. But if the soul is self-motion and if its causality is "primary" (cf. $46 \mathrm{D}-\mathrm{E}$ ), then, it follows that soul is the source of all motion and consequently the precosmical chaos cannot have been meant by Plato to be taken literally. This is why Plato avoided stating openly the identity of soul with self-motion, while at the same time giving enough indications that this is his conception.

37. This is precisely the point raised by the criticism of Aristotle which Xenocrates tried to answer (fragment 68 [Heinze]); but in doing so Xenocrates, as well as Aristotle, did not take into consideration the fact that Plato declared that the source of all motion must be self-motion because motion cannot be analyzed into factors which are not motion (cf. Cherniss, I, pp. 412-413 and note 366). This is why Plato, to "explain" motion, postulated the existence of a non-physical self-motion: the soul.

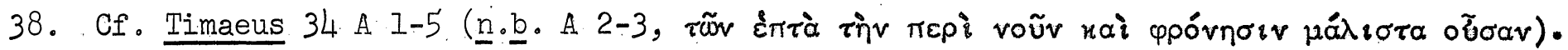

39. Since it is the soul that moves the body of the universe and the soul the one who possesses the "movement" proper to NOUS. (Cf. also $36 \mathrm{E}, 37 \mathrm{~A}-\mathrm{C}, 39 \mathrm{C}, 40 \mathrm{~A}, 77 \mathrm{~B}-\mathrm{C}, 90$ C-D). See also note 29.

40. Timaeus 34 B 10-35 A 1 .

41. Timaeus $35 \mathrm{~A}-36 \mathrm{~B}$.

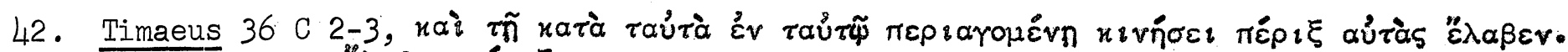
However one translates $\varepsilon_{\lambda a \beta \varepsilon v} \pi \varepsilon p \imath \xi$ one is forced to conclude that either the Demiurge places the soul into a pre-existing motion and, therefore, the world-soul has no power to move itself, or that the Demiurge imparts motion to the self-moving soul. The third possibility is that the creation of the soul was not meant to be taken literally (see also note 47).

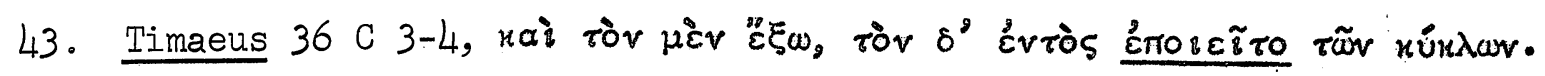




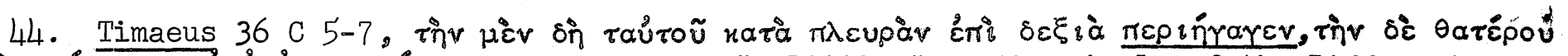

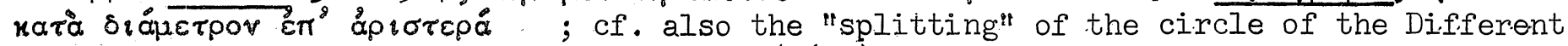
into seven circles having different speeds (36 D)。

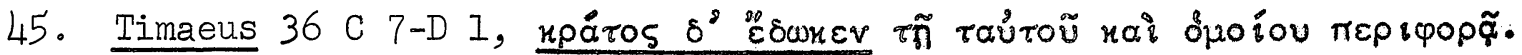

46. Timaeus $36 \mathrm{E} 2-5$; that is, the soul, having been placed into its motion, is moving and, once it is interwoven with the body of the universe, makes a beginning of ceaseless and intelligent life (i.e., the life of the universe, a living creature composed of soul and body; cf. 30 B I-C I and 34 B 8-9).

47. It is interesting to compare 34 B 3-9 with 36 D 8-E 5. In the first passage the Demiurge sets the soul in the body. while in the second he fashions the body within the soul. These two parallel accounts show that the fashioning of soul and body are contemporary and cannot have been meant literally since the Demiurge "created" first the soul and then the body of the universe. This double account when set against the warning given in 34 B 10-35 A 1 leads to the conclusion that this passage, calling attention to the reversal in the narrative of the mythical order of creation, is a hint to the reader not to take the creation literally.

48. After all Plato's purpose is to isolate and show the work of the two "efficient" causes in the universe (cf。especially $46 \mathrm{D}-\mathrm{E}$ and $69 \mathrm{~A}-\mathrm{B}$ )。

49. Cf. Cornford, Plato's Cosmology, p.3I, second paragraph. See also section V.

50. There is a striking reminiscence of the Phaedrus in $41 \mathrm{E}$ ff. (cf. Cornford, Plato's Cosmology, p.144). Though we cannot assume that Plato considers that the reader of the Timaeus knows the Phaedrus, this reminiscence may help us to understand what was in Plato's mind.

51. Cf. Timaeus $46 \mathrm{D}-\mathrm{E}$ : primary causation is that of NOUS, but NOUS can only exist in a soul (cf. note 34 ).

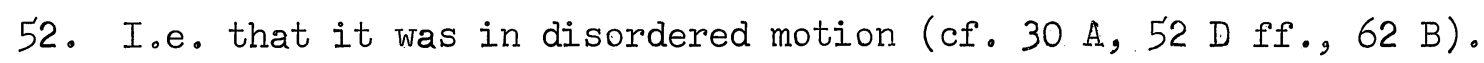

53. See, especially, Timaeus 37 C-38 C.

54. Vlastos, Creation, pp.410-411.

55. Vlastos, op.cit. p. 413 .

56. Cf. Cicero, De Natura Deorum I.9.21: ...saecla nunc dico non ea quae dierum noctiumque numero annuis cursibus conficiuntur; nam fateor ea sine mundi conversione effici non potuisse; sed fuit quaedam ab infinito tempore aeternitas, quam nulla circumscriptio temporum metiebatur, spatio tamen qualis ea fuerit intellegi potest, quod ne in cogitationem quidem cadit ut fuerit tempus aliquod nullum cum tempus esset. Why an Epicurean would distinguish a precosmic from a cosmic time is, I think, intelligible. Cf also Proclus, In Timaeum, vol.

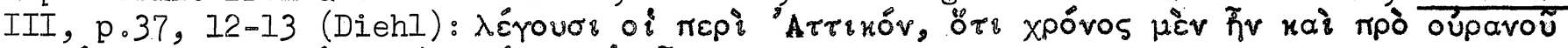

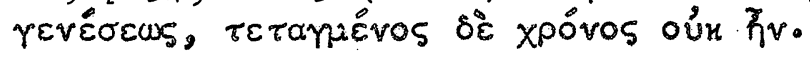

57. De Caelo 279 B 12-13: All say that the world has come into being, and some maintain that, having come into being, it is imperishable; in 280. A 28-32 the Timaeus is cited for this notion. Physics $251 \mathrm{~B} 14 \mathrm{ffo:}$ all agree that time is ungenerated, except Plato who generates it, since he makes it contemporaneous with the universe which has been generated. 
1. 58. Cf. Timaeus 38 C 4, iva revrneñ xpơros.

59. Cf. Timaeus 37.E 3-38, A 2. Vlastos (Creation, pp. 411-412) denies that Plato's

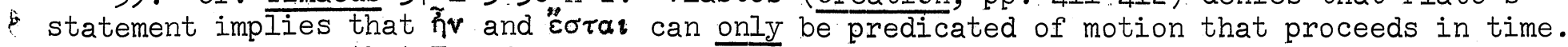
He says: "To say that $F$ and $G$ come into existence as attributes of $\underline{x}$ when $\underline{x}$ comes into existence is uninformative as to any prior instantiation of $F$ and $G$ " But what Plato says about time and its "parts" is not a case of accidental predication as Vlastos' example is. Plato

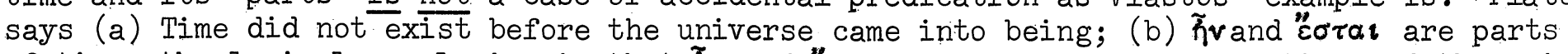

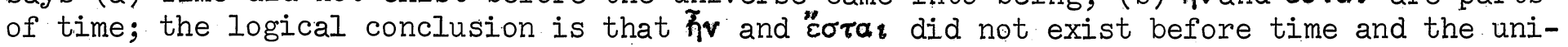
verse were generated. This is precisely the place where Plato would have differentiated a precosmic from a cosmic time if he so wished; since he did not, we can only understand him as saying that there was a time when time was not; since this is a contradiction we must assume either that he did not see it or that he purposely insisted in it several times to call attention to the fact that the creation should not be taken literally. I can say. "green and blue became predicates of grass and the sea when the latter came into being" and to this VIastos' example would apply; but if I say "green and blue became predicates (or "parts") of color when color was created," I must mean that there was no instance of green and blue before color was created.

60. This is why time is called an "eternal image" of the ideal model at 37 D. 7 .

61. I see no reason why Plato should specifically distinguish time (U) from time (S) only to deny that the latter exists. The assertion that the Demiurge generated time contemporaneously with the universe "in order that, as they were brought into being together, so they may be dissolved together, if ever their dissolution should come to pass" (38 B), is a tacit denial of the possibility of a time $(S)$.

62. So Aristotle and Eudemus. The latter said that Plato's definition of time (which he misinterpreted in the same way Aristotle did [cf. Cherniss, I, pp. 4l7 f., and note 348]) is inconsistent with the existence of a precosmic motion since all motion is in time (Simplicius, Phys., p.702, 24-29= Eudemus, fr. 46 [Spengel] = fr. 82 b [Wehrli]). For Aristotle's criticism, cf. note 64 .

63. Cf., for example, Proclus, ap. Philoponus, De Aeternitate Mundi, pp. 103,1-104,3 (Rabe).

64. Consequently, had Plato meant the creation of time to be taken literally, Aristotle's criticism (Physics 251 B $19 \mathrm{ff}$ ), that time must be unlimited because it implies the instant which is the limit between past and future time, would be valid. Vlastos (Creation, p.413 and note 1) denies that there is a logical reason why time must extend infinitely into the past, and asserts that "if it did not, one 'now' (the first) 'would have no 'before'." We must take into consideration, however, that Plato himself was aware of the definition of "now" as the limit between past and future, since he uses it in the Parmenides (152 B-E). At any rate, the notion of a first "now" which would have no "before presupposes the existence of a creator, a notion to which Aristotle would not subscribe (therefore, his criticism at least is valid from his own point of view), which he does not attribute to Plato, and which is incompatible with Plato's conception of the divine (cf. section IV).

65. Timaeus $4 I$ A 3 ff.

66. Timaeus 42 E 5-6.

67. Cf. Proclus, In Timaeum, vol. I, p.288, 14-27 (Diehl).

68. Cf. Proclus, op.cit.; Cherniss, I, p. 425.

69. Republic 381 B-C. 
70. Vlastos, Creation, p.406.

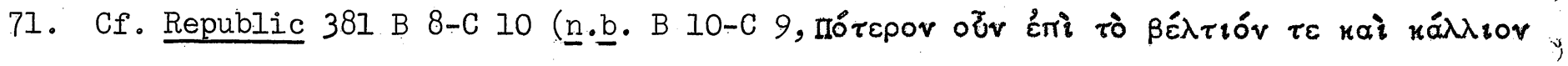

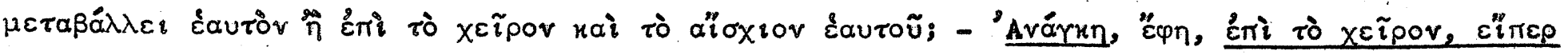

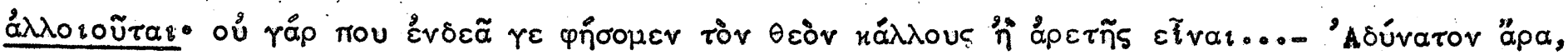

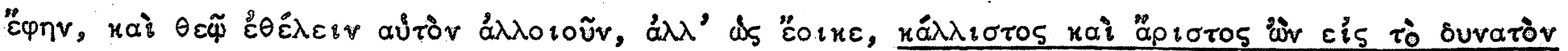

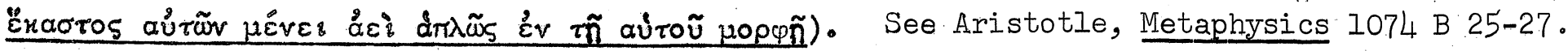

72. Cf. Timaeus $42 \mathrm{E} \mathrm{5-6.} \mathrm{God} \mathrm{is} \mathrm{the} \mathrm{best} \mathrm{of} \mathrm{causes} \mathrm{and} \mathrm{his} \mathrm{work} \mathrm{is} \mathrm{good,} \mathrm{cf.} 28 \mathrm{~A}$ 6-B I, 29 A 2-6, $29 \mathrm{E}-30 \mathrm{~B}$, etc.

73. Timaeus 29 E 1-2; Phaedrus 247 A; cf. Aristotle, Metaphysics 983 A 2-4.

74. Cf. Cicero, De Natura Deorum I.9.21: ab utroque autem sciscitor cur mundi aedificatores repente exstiterint, innumerabilia saecla dormierint; cf. Lucretius V.168-173; and see especially Proclus, In Timaeum, vol. I, p.288, 17-27 (Diehl); This kind of argument is at least as old as Parmenides (cf. Parmenides 28 B 8, 9-10, $\tau i$ on "av $\mu \imath v$

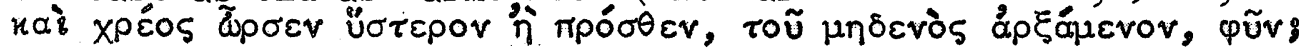

and see my Parmenides [Princeton, 1965], pp. 102 f.).

75. Cf. above note 34 .

76. Cf. Euthyphro 10 A-II A.

77. Laws $818 \mathrm{~A}-\mathrm{E}$.

78. Cf. Laws 818 B 9-C 3, for the interpretation of which see Cherniss, I, pp.608-9.

79. Phaedrus 247 D-E.

80. Cf.Hackforth, Plato's Phaedrus (Cambridge, 1952), p.78, note 1, and p.80.

81. Phaedrus 249 C 5-6.

82. Timaeus 46 E 4 .

83. Cf.Grube, Plato's Thought (London, 1935), p.169; Cornford, Plato's Cosmology, pp. 38 and 280 .

84. Sophist 265 B-E.

85. Politicus 270 A, 273 A-C.

86. Politicus 273 B-D.

87. Cf. Republic 507 C 6-8, 529 D-530 B (cf. also 532 C I with Shorey, Plato, The Republic, vol. II, p.I99, note b).

88. Republic 530 A 5-7.

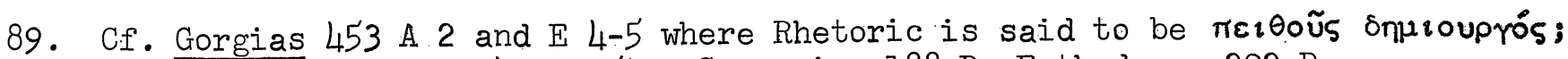
cf. also $45^{\circ}$ A-E; Charmides 174 E-175 A; Symposium $188 \mathrm{D}$; Euthydemus 29.2 D. 
4. 90. De Generatione et Corruptione 336 B 27-34; this notion is the same as that implied by Plato in Timaeus 37.C-D (ef. Cherniss, I, p.420 and notes 126 and 352).

91. Cf. Cherniss, I, pp. 609 f.

92. Timaeus 28 B 7 .

93. Hackforth, Classical Quarterly, N.S. IX (1959), pp. I8f.

94. Vlastos, Creation, pp. 402-405.

95. Timaeus 28 B 6-7.

96. Timaeus 28 B 4-C 2 .

97. Vlastos, Creation, p. 402.

98. Cf. Zeller, Die Philosophie der Griechen, II, ${ }^{5}, p .793$. The point had already been raised by Proclus, In Timaeum, vol. I, pp. 283,27-285, 7 (Diehl)。

99. Cf. Cherniss, I, note 361.

100. Timaeus 30 A 3.

101. Cf. Vlastos, Creation, pp. 403-405.

102. Cf. Timaeus 52 D 3-4,

103. Cf. Alcinous, Epitomé XIV, 3 (Louis); Taurus, ap. Philoponus, De Aeternitate Mundi, pp. 145,8-147,13 (Rabe); Proclus, In Timaeum, vol. I, pp. 290,13-291,12 (Diehl); Asclepius, In Nicomachi Isagogen I, $\gamma$, sub fin. (in my edition of this work which is still unpublished).

104. Solmsen (Aristotle's System of the Physical World [Ithaca, 1960],p.51), while recognizing that "there are definite reasons why Plato's cosmos should have no temporal beginning," says that "we have no right to give them more weight than did Plato himself and to set aside his unequivocal and emphatic statement that the Cosmos 'has come into being.!.i. The arguments for the eternity of the Cosmos become decisive only with his pupils." Solmsen (op.cit. p.50, note 114) appears to think that Plato himself gives a warning against going beyond the myth

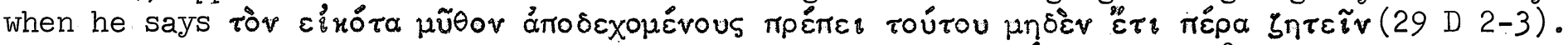
I have given my reasons against such an interpretation of yérover in 28 B 7 . I would like to add that the fact that the mythical form may be intimately connected with a subject does not mean that we cannot derive conclusions that go beyond the myth. Moreover, we should distinguish in the Timaeus two things which could be einos: on the one hand we have the mythical account of creation, on the other the content of Timaeus' discourse about the physical world. Now 29 D2-3 is Timaeus' conclusion from the fact that his discourse is about the universe which

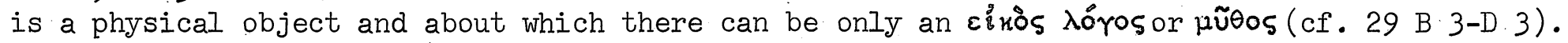
An examination of the different passages where Plato uses these expressions will show that it is the content of the physical doctrines propounded by Timaeus that is declared to be "likely," or as "likely" as any other, not the creation myth itself. Finally, that Plato was interested in the question whether the universe had a beginning or not is shown by the Timaeus

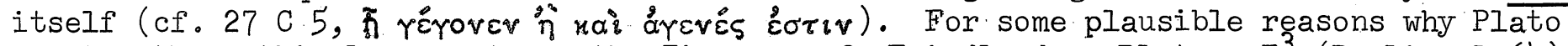
adopted the mythical account for the Timaeus, cf. Friedlander, Platon, I3 (Berlin, 1964), pp. 2l1-2 = Plato, Vol. I (New York, 1958), p.200. See also in the English edition p.248, a passage which has apparently been omitted from the last German edition.

105. Cf. especially 46 D-E. 